\title{
Infected Orthokeratinized Odontogenic Cyst: A Rare Cause of Facial Cellulitis
}

\author{
Cyntia Helena Pereira de CARVALHO \\ Ana Rafaela Luz de AQUINO ${ }^{1}$ \\ Cassiano Francisco Weege NONAKA ${ }^{1}$ \\ José Sandro Pereira da SILVA ${ }^{2}$ \\ Adriano da Rocha GERMANO ${ }^{2}$ \\ Leão PEREIRA PINTO ${ }^{1}$
}

\author{
${ }^{1}$ Department of Oral Pathology, Dental School, UFRN - Federal University of Rio Grande do Norte, Natal, RN, Brazil \\ ${ }^{2}$ Department of Oral and Maxillofacial Surgery, Dental School, \\ UFRN - Federal University of Rio Grande do Norte, Natal, RN, Brazil
}

\begin{abstract}
Orthokeratinized odontogenic cysts (OOCs) are relatively uncommon developmental cysts lined with orthokeratinized epithelium consisting of a prominent granular layer and a basal layer of low cuboidal flattened cells that show no tendency for nuclear palisading. These cysts have been considered a distinct entity from odontogenic keratocysts since they exhibit a less aggressive behavior and a very low rate of recurrence. Developmental odontogenic cysts can become infected but serious complications, such as potentially life-threatening cellulitis, are rare. This report describes a rare case of facial cellulitis secondary to an infected OOC located in the mandible of a 27-year-old man. The relevant literature about the clinical-pathological features of OOC is reviewed.
\end{abstract}

Key Words: odontogenic cyst; orthokeratinized odontogenic cyst; facial cellulitis.

\section{INTRODUCTION}

The orthokeratinized odontogenic cyst (OOC) was first identified by Wright in 1981 as an individual entity distinct from other odontogenic cysts (1). Several studies subsequently discussed the true nature and the histopathological classification of OOCs $(2,3)$.

This cyst usually presents as an asymptomatic, solitary, radiolucent lesion located in the posterior mandible, which mainly affects White patients between the third and fourth decades of life $(2,4,5)$. Developmental odontogenic cysts can become infected but potentially life-threatening cellulitis, such as Ludwig's angina and mediastinitis, is rarely observed associated with this entities (6). Reports of infected OOCs are very rare in the literature (4).

This report presents a rare case of facial cellulitis secondary to an infected OOC located in the mandible of a young man. The literature referring to the clinical and pathological features of $\mathrm{OOC}$ is also reviewed.

\section{CASE REPORT}

A 27-year-old man was seen for evaluation of a tender swelling in the region of the left cheek. On admission, the patient was slightly febrile $\left(38^{\circ} \mathrm{C}\right)$ and reported that he had undergone antibiotic treatment and intraoral drainage 1 month earlier, without improvement of symptoms. Extraoral physical examination showed floating facial edema in the region of the left cheek. The overlying skin was normal in color and there was no evidence of a cutaneous fistula. His medical history showed no associated systemic diseases. Intraoral examination revealed limited mouth opening and purulent discharge from a fistula located in the region of the mandibular left first molar. In addition, the left third molar was covered on the distal side with inflamed gingiva. Panoramic radiography revealed a unilocular radiolucent lesion in the left mandibular angle and ramus (Fig. 1A). Computed tomography showed a large cystic lesion measuring about $8 \times 5 \mathrm{~cm}$, which caused thinning

Correspondence: Prof. Dr. Leão Pereira Pinto, Universidade Federal do Rio Grande do Norte, Departamento de Odontologia, Avenida Senador Salgado Filho 1787, Lagoa Nova, 59056-000 Natal, RN, Brasil. Tel/Fax:+55-84-3215-4138. e-mail: lppinto@digi.com.br 
and perforation of the mandibular cortical plates (Fig. $1 \mathrm{~B}$ and $1 \mathrm{C}$ ). On the basis of the initial clinical diagnosis of facial cellulitis secondary to a paradental cyst, the patient was admitted and intravenous antibiotic therapy with penicillin $\mathrm{G}(4,000,000 \mathrm{IU})$ plus metronidazole $(500 \mathrm{mg})$ was administered for 5 days. In addition, the patient was submitted to oral physical therapy to improve mouth opening and received warm and moist compresses, followed by extraoral drainage (Fig. 2) under general anesthesia. The patient's clinical condition improved after 1 week and the lesion was treated by enucleation, followed by peripheral ostectomy. The surgical specimen was fixed in $10 \%$ neutral formalin and submitted to histopathological analysis.

Histopathological examination revealed a cystic cavity lined with orthokeratinized epithelium with an average thickness of 10-12 cells. The orthokeratinized surface layers were relatively thick and there was a prominent granular cell layer beneath them. The basal layer cells exhibited a cuboidal morphology with no tendency for nuclear hyperchromatism or palisading

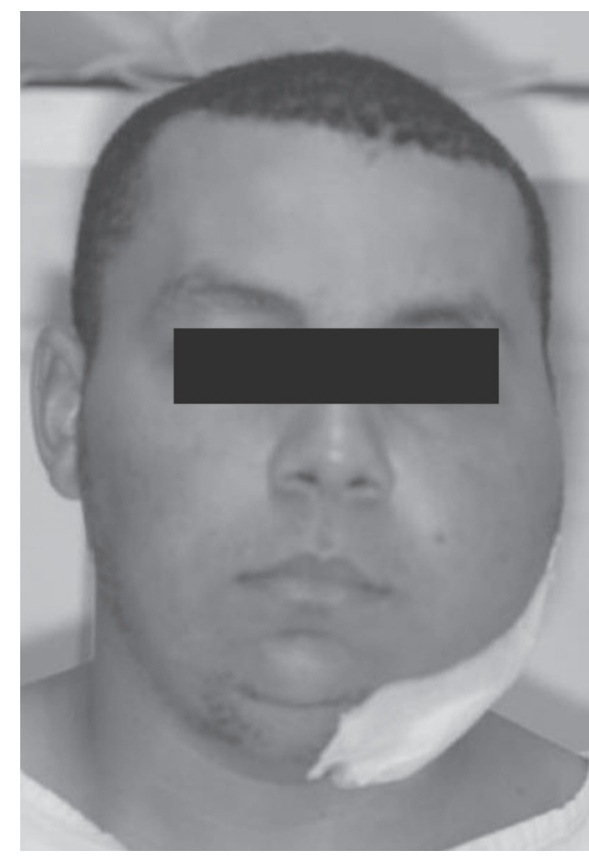

Figure 2. Patient's appearance immediately after extraoral drainage.
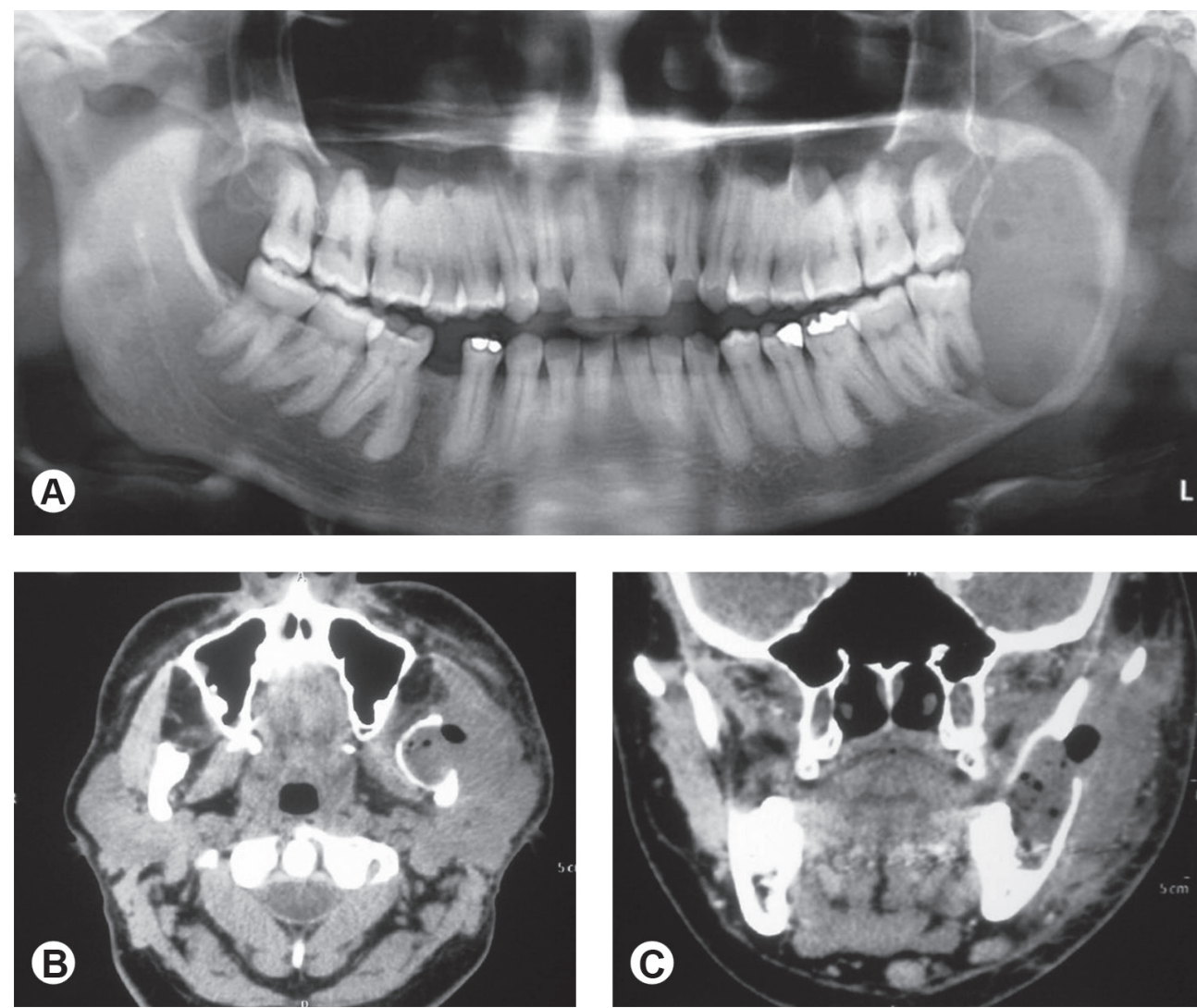

Figure 1. Composite figure of radiological images. A: Panoramic radiograph revealing a unilocular radiolucent lesion in the left mandibular angle and ramus. B and C: Axial and coronal CT scans showing a large cystic lesion with thinning and perforation of the mandibular cortical plates. 
(Fig. 3A). The fibrous capsule consisted of dense fibrous connective tissue with foci of intense inflammatory infiltration of polymorphonuclear cells (characteristic of damage associated with an abscess), which caused changes in the cystic epithelium (Fig. 3B). The microscopic findings led to the diagnosis of OOC. The patient progressed well and was discharged after 3 days. The facial swelling had regressed completely 45 days after surgery and radiographic examination performed 8 months later revealed good bone healing (Fig. 4).

\section{DISCUSSION}

OOC is a distinct type of odontogenic cyst (1), which is characterized by a less aggressive behavior and a low rate of recurrence $(2,4)$. This developmental
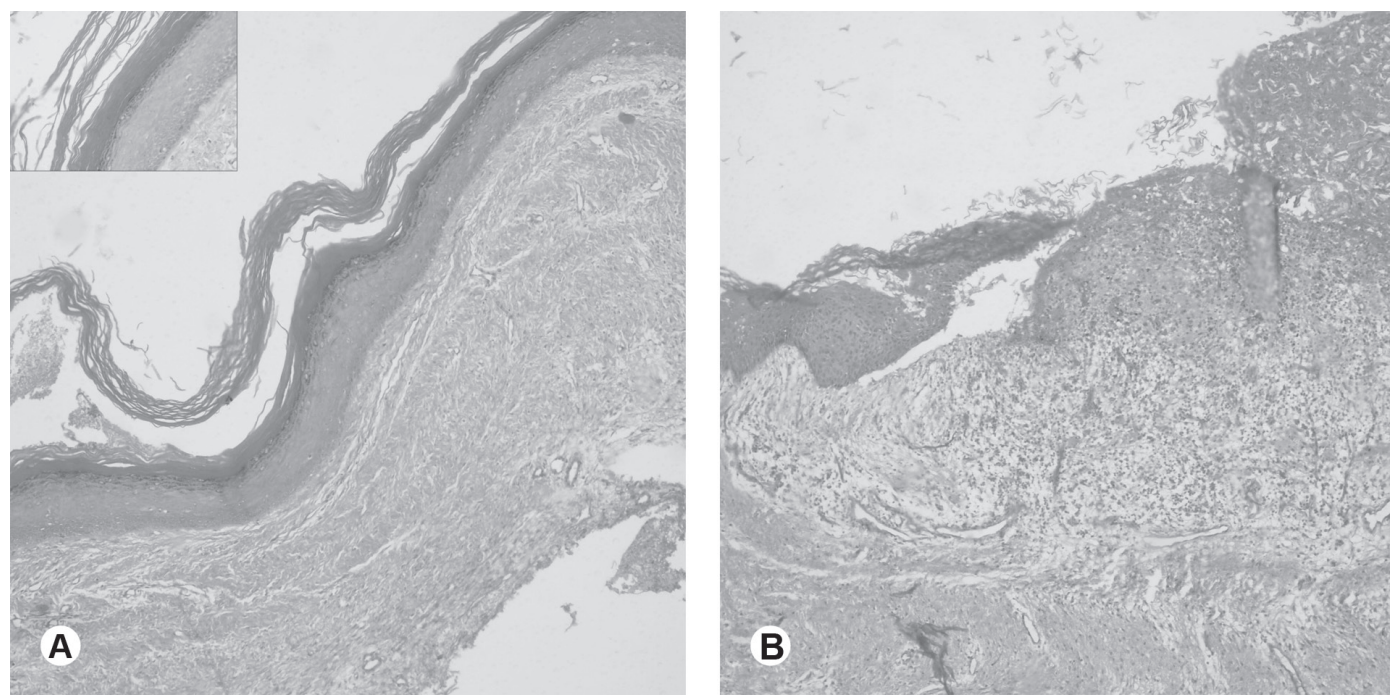

Figure 3. Composite figure of photomicrographs. A: Cystic cavity lined with orthokeratinized epithelium $(\mathrm{HE}, \times 100)$, in detail orthokeratinized surface layers relatively thick and prominent granular cell layer beneath them $(\mathrm{HE}, \times 400)$. B: Foci of intense inflammatory infiltration of polymorphonuclear cells in fibrous capsule (characteristic of damage associated with an abscess), with changes in the cystic epithelium $(\mathrm{HE}, \times 100)$.

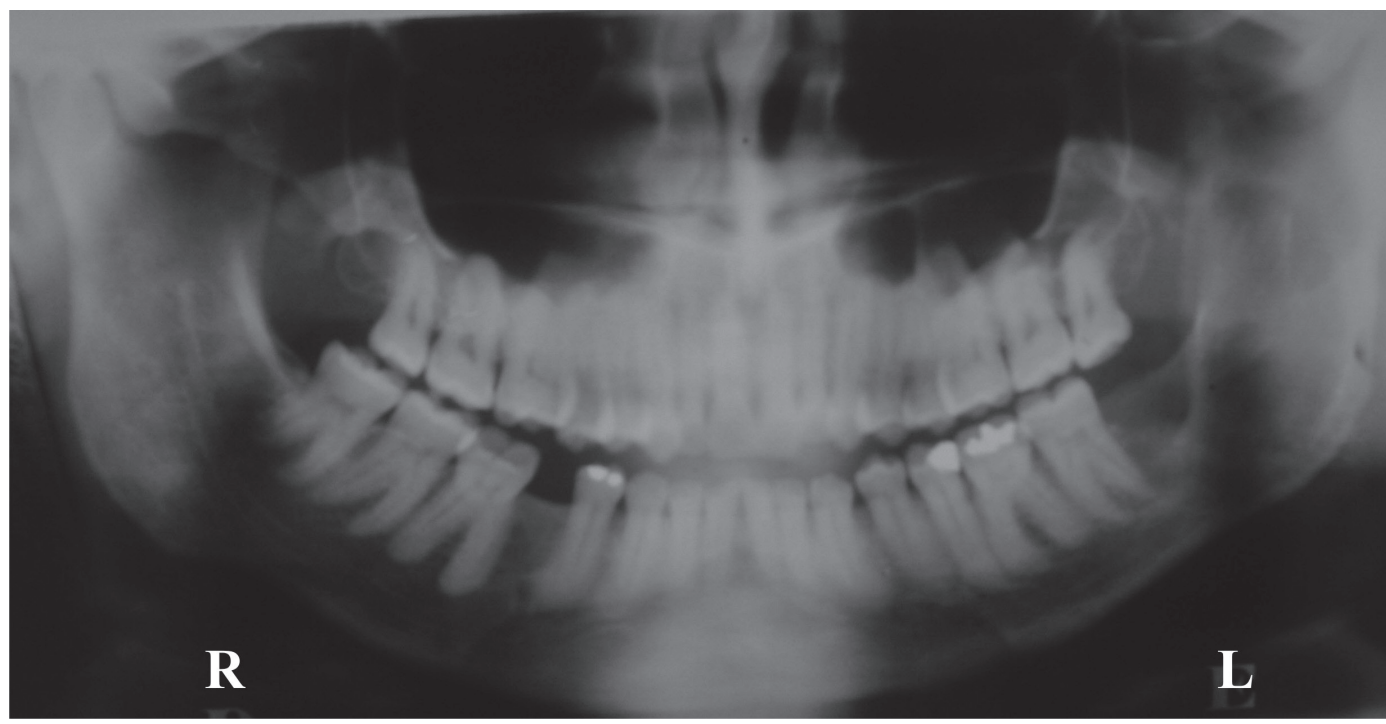

Figure 4. Panoramic radiograph 8 months after surgery revealing good bone healing. 
cyst is relatively rare $(3,7)$. Its incidence varies among different series, ranging from $16.8 \%$ of cases previously classified as odontogenic keratocyst (3) to only $0.4 \%$ of all odontogenic cysts (7). A male preference has been reported for OOC, with a male-to-female ratio of 2:1 to $2.59: 1(2,4)$. The peak incidence is in the third to fourth decade of life $(2,4)$. The present case agrees with the profile commonly reported for patients with OOC.

Clinically, OOC usually presents as a slowly growing, asymptomatic jaw swelling $(2,4,5)$, but pain is reported as a symptom by some patients $(4,8)$. As demonstrated in case series, the mandible is more commonly affected than the maxilla and the most common location is the molar and ramus area of the mandible $(1,4)$. Radiographically, OOC appears as a well-defined unilocular radiolucency, but multilocular lesions have also been reported (4,5). An association with impacted teeth is seen in $46.7 \%$ to $75 \%$ of cases (1-5) and the diameter of these cysts commonly ranges from 2 to $7 \mathrm{~cm}(2,3)$.

Except for its anatomical location, the clinical and imaging features of the present case somehow differ from those commonly reported for OOCs. In contrast to other reports, the present OOC was relatively large $(8 \times 5 \mathrm{~cm})$ and showed thinning and perforation of the mandibular cortical plates, features that might be related to the presence of infection. Secondary infection is an uncommon event in developmental odontogenic cysts (6). In a retrospective study of 327 cases of head and neck infection (10), dentigerous cysts were the underlying causative pathology in only seven $(2.1 \%)$ cases. In line with this report, in a case series of 61 OOCs, only two (3.3\%) patients presented infection (4).

In rare cases, developmental odontogenic cysts with secondary infection can give rise to serious complications such as potentially life-threatening cellulitis. These complications are more commonly reported for dentigerous cysts $(6,9)$. Although the clinical-imaging features of the present case were suggestive of a paradental cyst as underlying causative pathology, the lesion was identified as an OOC by histopathological analysis. Possibly, the secondary infection was the consequence of a stagnation area on the distal side of the mandibular left third molar. To the best of our knowledge, there are no reports of facial cellulitis secondary to an infected OOC. Thus, the present case highlights the importance of including OOC in the differential diagnosis of developmental odontogenic cysts with secondary infection and emphasizes the need for routine histopathological examination of the removed surgical specimens.

Despite some similarities in the microscopic features of OOCs and odontogenic keratocysts (e.g., squamous stratified epithelium, keratinization, and relatively similar epithelial thickness), these cysts are fundamentally different (8). Histologically, the basal cells of OOCs are much less developed than those of odontogenic keratocysts. The cells tend to be cuboidal and show little tendency to polarize or palisade (8). In addition, OOCs have a luminal surface of orthokeratin and a well-developed granular layer (4). The higher recurrence rate, aggressive behavior, and neoplastic potential of odontogenic keratocysts highlight the importance to distinguish between odontogenic keratocysts and OOCs $(2,4)$.

In the case of developmental odontogenic cysts with secondary infection, treatment with antibiotics to eradicate the infection should be initiated prior to definitive surgical management of the cyst $(10,11)$. Coherently, the present patient was subjected to intravenous antibiotic therapy with penicillin $G$ (4,000,000 IU) and metronidazole (500 mg), followed by extraoral drainage. OOCs show little if any tendency to recur and may be treated conservatively by simple enucleation with or without curettage $(2,8)$. Some cases of OOC presenting multilocular features upon radiography and a relatively large size have been treated by enucleation with peripheral ostectomy (4). In view of the presence of secondary infection and the relatively large size of the cyst, the present case of OOC was treated by enucleation with peripheral ostectomy. Radiographic examination performed 8 months after surgery showed good bone healing. Despite the little tendency toward recurrence of OOC, the patient remains under careful follow-up.

\section{RESUMO}

Os cistos odontogênicos ortoceratinizados (COOs) são cistos de desenvolvimento revestidos por epitélio ortoceratinizado constituído por uma camada granulosa proeminente e uma camada basal de células cuboidais achatadas que não mostram tendência à paliçada. Esses cistos foram considerados uma entidade distinta dos ceratocistos, uma vez que apresentam um comportamento menos agressivo e uma taxa muito baixa de recorrência. Cistos odontogênicos de desenvolvimento pode tornar-se infectados, mas complicações graves como a celulite, potencialmente ameaçadora da vida, são raros. Este relato descreve um caso raro de celulite facial secundária a um COO infectado localizado na mandíbula de um homem de 27 anos de idade. A literatura relevante sobre as características clínicopatológicas do $\mathrm{COO}$ foi revisada. 


\section{REFERENCES}

1. Wright JM. The odontogenic keratocyst: orthokeratinized variant. Oral Surg Oral Med Oral Pathol 1981;51:609-618.

2. Li TJ, Kitano M, Chen XM, Itoh T, Kawashima K, Sugihara K, et al.. Orthokeratinized odontogenic cyst: a clinicopathological and immunocytochemical study of 15 cases. Histopathology 1998;32:242-251.

3. Vuhahuhla E, Nikai H, Ijuhin N, Ogawa I, Takata T, Koseki T, et al.. Jaw cysts with orthokeratinization: analysis of 12 cases. J Oral Pathol Med 1993;22:35-40.

4. Dong Q, Pan S, Sun LS, Li TJ. Orthokeratinized odontogenic cyst: a clinicopathologic study of 61 cases. Arch Pathol Lab Med 2010;134:271-275.

5. MacDonald-Jankowski DS, Li TK. Orthokeratinized odontogenic cyst in a Hong Kong community: the clinical and radiological features. Dentomaxillofac Radiol 2010;39:240-245.

6. Basa S, Arslan A, Metin M, Sayar A, Sayan MA. Mediastinitis caused by an infected mandibular cyst. Int J Oral Maxillofac Surg 2004;33:618-620.
7. Souza LB, Gordón-Núñez MA, Nonaka CW, Medeiros MC, Torres TF, Emiliano GBG. Odontogenic cysts: demographic profile in a Brazilian population over a 38-year period. Med Oral Patol Oral Cir Bucal 2010;15:583-590.

8. Sciubba JJ, Fantasia JE, Kahn LB. Odontogenic cysts. In: Atlas of tumor pathology. Tumors and cysts of the jaw. Washington: Armed Forces Institute of Pathology; 2001,pp15-56.

9. Metzger MC, Wagner KW, Hohlweg-Marjet B, Voss PJ, Schoen R, Schmelzeisen R. Diplopia and acute rectus muscle palsy as symptoms of an infected follicular cyst of a maxillary right third molar: a case report. Quintessence Int 2007;38:571-574.

10. Smith JL, Kellman RM. Dentigerous cysts presenting as head and neck infections. Otolaryngol Head Neck Surg 2005;133:715-717.

11. Lautenschläger GAC, Gallina MC, Ferreira Júnior O, Lar VS. Primary failure of tooth eruption associated with secondarily inflamed dental follicle: inflammatory follicular cyst? Braz Dent J 2007;18:144-147.

Received April 26, 2012

Accepted September 26, 2012 